\title{
Resistance of important bean genotypes to the Mexican bean beetle [Zabrotes subfasciatus (Bohemann)] during storage and its control with chemical synthetic and botanical insecticides
}

\author{
Carlos E.A. Luz ${ }^{1}$, Tamíris A. Araujo ${ }^{1}$, Arthur V. Ribeiro ${ }^{1}$, Cristina S. Bastos ${ }^{2 *}$, Jorge B. Torres ${ }^{3}$, Yann \\ S.T. Krieger ${ }^{3}$
}

${ }^{1}$ Departamento de Entomologia (DDE), Universidade Federal de Viçosa (UFV), Campus Universitário s/no., 36570-000, Viçosa, MG, Brazil

${ }^{2}$ Universidade de Brasília (UnB), Faculdade de Agronomia e Medicina Veterinária (FAV), Instituto Central de Ciências Ala Sul (ICC-SUL), Campus Darcy Ribeiro, 70910-900, Asa Norte, Brasilia, DF, Brazil

${ }^{3}$ Universidade Federal Rural do Pernambuco (UFRPE), Departamento de Agronomia-Entomologia (DEPA), 52171-900, Dois Irmãos, Recife, PE, Brazil

*Corresponding author: cschetino@unb.br; cschetino@gmail.com

\begin{abstract}
During storage, beans can be infested with many insect-pests including Zabrotes subfasciatus, a key pest of these crops. This study aimed to identify bean genotypes demonstrating antixenosis and/or antibiosis to Z. subfasciatus and to test their integration with chemical control. The ultimate goal of assessment was to distinguish whether genotypic and insecticidal factors can provide effective beetle control. The tested genotypes were (a) Phaseolus vulgaris group: CCB, BSCB, BCB and PCB; (b) Vicia faba group: YBB, WBB and SBB; and (c) Vigna unguiculata group: C and GC. Initial assays were run to select genotypes (without insecticide treatment) that would be further tested with insecticides. Final assays included genotypes with varying degree of antibiosis and antixenosis treated with a neem formulation (Natuneem ${ }^{\circledR}$ ) and distilled water (control) plus deltamethrin (Decis $\left.{ }^{\circledR}\right)$ which latter was used only in the final antibiosis assay. The insecticides were used at the rates of 3 and $0.1 \mathrm{~mL}$ of Natuneem ${ }^{\circledR}$ and Decis ${ }^{\circledR}$, respectively, per $30 \mathrm{~mL}$ of distilled water. There were no differences in preference of Z. subfasciatus adults among non-treated genotypes (initial assays), although neem-treated genotypes altered the preference and reduced infestation from 40.54-100\% (final assays). In antibiosis tests, oviposition and density of emerged adults were reduced among C and SBB, and SBB also reduced the weight of emerged adults. Insecticides reduced oviposition in 53-100\% and yielded half to five-fold fewer emerging insects weighting 35\%-40\% less in antibiotic genotypes. SBB was the most antibiotic genotype and this and other genotypes possessing antibiosis had a synergistic effect with neem or deltamethrin.
\end{abstract}

Keywords: Zabrotes subfasciatus, antibiosis, antixenosis, neem, deltamethrin.

Abbreviations: BCB_Black Common Bean; BSCB_Brown Spotted Common Bean; CCB_Carnival Common Bean; C_Cowpea; GC_Greenly Cowpea; PCB_Purple Common Bean; SBB_Spotted Broad Bean; WBB_White Broad Bean; YBB_Yellow Broad Bean.

Introduction

The common bean (Phaseolus vulgaris L. Fabaceae) possesses high protein content (Hosfield, 1991) and is a dietary staple in the Americas and Africa countries. The broad bean (Vicia faba L. Fabaceae) and cowpea (Vigna unguiculata L., Walp. Fabaceae) are also commonly consumed in northeastern Brazil. They serve as an alternative protein source to the Brazilian population, reducing the nation's dependence on common beans (Frota et al., 2008). Together, these beans have a special importance in the diet of Brazilians and throughout the tropics due to their low cost of production compared with animal protein. The protein content in these Fabaceae species varies from $16 \%$ to $33 \%$ (Frota et al., 2008). Appropriate storage helps to reduce the effects of seasonality and variation in prices over the growing season and to maintain the quality of the seeds over time (Brackmann et al., 2002). However, it can also increase the chances of pest infestation and dissemination. The Mexican bean beetle (MBB), Zabrotes subfasciatus (Bohemann) (Coleoptera: Chrysomelidae: Bruchinae), is a key pest of stored beans, attacking beans belong to the genera Phaseolus,
Vicia and Vigna (Hill, 2002). In Brazil, MBB also infests other types of beans such as Vicia and Vigna and other legumes such as peas (Pisum sativum L. Fabaceae) probably because of the presence of a great number of digestive proteinases that exist in the insect's midgut (Magalhães et al., 2007). Infested seeds lose mass, quality and nutritional value, the latter two due to the presence of frass, eggs and dead insects in the product. In Brazil, losses attributed to this pest can vary from $7 \%$ to $15 \%$ of the seeds, reaching up to $40 \%$ in the northeast of the country (Mazzoneto and Vendramim, 2002). The control of this beetle is mainly insecticide-based, involving the use of fumigant (aluminum and magnesium phosphide) and contact (deltamethrin) products, which together, comprise all of the molecules registered for this purpose (Brasil, 2017). Although the control level achieved by these chemicals is satisfactory, the limited amount of registered molecules increases the risk of resistance of insects to these products. Also, toxicological issues limit their widespread use (Gutierrez et al., 1981). An alternative approach to reduce this array of problems is the adoption of 
resistant cultivars. Such an approach may have several advantages, including seed cost that partially encompasses the cost of arthropod control, reduction in insecticide costs and residues, higher net return per dollar invested and synergistic effects with other traditional pest management tactics, to mention only a few (Smith, 2005). Some previous studies have considered the exploitation of genotypes possessing variable degrees of arcelin (Acosta-Gallegos et al., 1998; Barbosa et al., 2000; Moraes et al., 2011). However, none of them have considered the resistance of different groups of beans belonging to different plant genera to this pest. Another possibility that should be considered in the pest control is the use of plant extracts or formulations possessing insecticidal activity, such as neem-based (Azadirachta indica A. Juss. Meliaceae) extracts or formulations. Commercial formulations are already available in Brazil and are currently in use for the control of field insect-pests (Brasil, 2017). One of the components of neem-based formulations, azadirachtinA, which has known insecticidal properties, degrades in light after 2.47 days, on average, on foliar surfaces (Johnson et al., 2003). Such formulations have not yet been tested against pests of stored products and their effectiveness under the prevailing conditions of stored environments (i.e., darkness) is of particular interest. However, the relative effectiveness of implementing control measures individually or in combination should be taken into consideration. The synergistic effects of combining pest control measures, such as using both Mexican bean beetle-resistant varieties and azadirachtin formulations, may increase pest mortality rates and improve the efficacy of pest control. The goal of this study was to select varieties of common beans, broad beans and cowpeas that have antixenosis or antibiosis resistance to the Mexican bean beetle and examine whether using bean genotypes with some levels of resistance in combination with neem and deltamethrin-based chemical formulations can provide more effective control of this key pest.

\section{Results}

\section{Non-preference}

\section{Selection of genotypes for further tests (initial assay)}

Bioassays run to select genotypes that would be further tested with neem-based formulation showed that the interaction of genotypes and time of evaluation was not significant according to repeated measures analysis of variance $\left(\mathrm{F}_{40,192}=\right.$ $1.20, P=0.25)$. Additionally, there was no significant effect of the genotypes $\left(\mathrm{F}_{5,24}=0.92, P=0.49\right)$. However, although cowpea $(0.85 \pm 0.04$ adults $)$ and greenly cowpea $(0.94 \pm 0.05$ adults) had lower densities of Z. subfasciatus per $20 \mathrm{~g}$ of seeds, black common bean (1.12 \pm 0.18 adults), purple common bean (1.07 \pm 0.07 adults) and white broad bean $(1.06 \pm 0.07$ adults $)$ had higher densities. Because of the absence of statistical significance and need to select the genotypes that should be included in subsequent assays, we chose the most and least preferred genotypes, based on differences on the numerical density of adult insects.

\section{Neem-treated seeds tests (final assays)}

Based on the results of the assays to select genotypes that should be further tested with neem formulation, three additional antixenosis bioassays were performed, in which we tested the following genotypes: black common bean (BCB), cowpea (C) and white broad bean (WBB) in the first bioassay; black common bean (BCB), cowpea (C) and purple common bean (PCB) in the second; and black common bean (BCB), greenly cowpea (GC) and cowpea (C) in the third.

In the first bioassay (Assay 1), we detected significant differences in the density of adults for the last two evaluation times $\left(36 \mathrm{~h}: \chi^{2}=7.49, \mathrm{p}<0.0236 ; 48 \mathrm{~h}: \chi^{2}=7.62, \mathrm{p}<\right.$ 0.0222 ). At 36 and $48 \mathrm{~h}$ from the beginning of the assay, white broad bean (WBB) and black common bean (BCB) had the greatest densities of $Z$. subfasciatus, while cowpea (C) had the lowest density (Fig 1A). However, the mean density of $Z$. subfasciatus across all evaluation times showed that while white broad bean (WBB) was most preferred (149 adults), black common bean (BCB) (72 adults) and cowpea (C) (49 adults) were the least preferred $\left(\chi^{2}=28.65\right.$; $\mathrm{p}<$ 0.0001 ). In the second antixenosis bioassay (Assay 2), the only significant effect detected was that associated with the treatment of seeds with neem. The neem-treated seeds were significantly less preferred by Z. subfasciatus (i.e., had lower densities of adult insects) than seeds that were treated with distilled water (control) at $0.5\left(\chi^{2}=6.00, p=0.0143\right), 2\left(\chi^{2}=\right.$ $6.93, \mathrm{p}=0.0084), 12\left(\chi^{2}=4.06, \mathrm{p}=0.0438\right), 24\left(\chi^{2}=4.97, \mathrm{p}\right.$ $=0.0297)$ and $48\left(\chi^{2}=4.59, \mathrm{p}=0.0321\right)$ hours after the beginning of the assay (Fig 1B). The same happened to the mean density of $Z$. subfasciatus across all evaluation times $\left(\chi^{2}=34.09, \mathrm{p}<0.0001\right)$. In the third bioassay (Assay 3), there was a significant effect only for the treatment of seeds with neem. The neem-treated seeds were preferred less than those treated with water in most of the evaluation times, with the exception of the first three $(0.5,1$ and $2 \mathrm{~h}$ after the beginning of the assay) that did not promote any significant differences (Fig 1C).

\section{Antibiosis bioassay (initial assay)}

\section{Selection of genotypes for further tests}

The tested genotypes contained different numbers of $Z$. subfasciatus eggs $\left(\mathrm{F}_{7,32}=4.89, P=0.0008\right)$ and yielded different numbers $\left(\mathrm{F}_{7,32}=4.73, P=0.0010\right)$ and masses of emerging adults $\left(\mathrm{F}_{7,32}=5.48, P=0.0003\right)$. The number of eggs of $Z$. subfasciatus was highest in brown spotted common bean (BSCB); intermediate in white broad bean (WBB), yellow broad bean (YBB), carnival common bean (CCB), black common bean (BCB) and purple common bean (PCB) and least in cowpea (C) and spotted broad bean (SBB) (Fig 2A). The same pattern held for emerged $Z$. subfasciatus adults, excepting for black common bean $(\mathrm{BCB})$ that grouped with cowpea (C) and spotted broad bean (SBB) (Fig 2A). However, the mean weight of emerged adults was highest at carnival common bean (CCB), brown spotted common bean (BSCB), white broad bean (WBB) and yellow broad bean (YBB), intermediate in black common bean (BCB), purple common bean $(\mathrm{PCB})$ and cowpea $(\mathrm{C})$ and lowest in spotted broad bean (SBB) (Fig 2B). Hence, based on these results, we selected spotted broad bean (SBB) and cowpea (C) as the two most resistant genotypes and yellow broad bean (YBB), brown spotted common bean (BSCB) and white broad bean (WBB) as the most susceptible genotypes.

\section{Insecticides-treated seeds tests (final assay)}

In analyzing density of $Z$. subfasciatus eggs, a significant interaction was found between genotypes and treated seeds $\left(\mathrm{F}_{8,60}=4.61, P=0.0002\right)$. Treating the seeds with both neem and deltamethrin significantly reduced the number of eggs laid by $Z$. subfasciatus in the majority of the genotypes tested. Exceptions to this pattern were found for brown spotted common bean, which had equal numbers of eggs in all treatments, and the spotted broad bean, which had reduced 
Table 1. Total number ( \pm standard error of the mean) of Zabrotes subfasciatus eggs obtained in an antibiosis bioassay according to the bean genotype treated with different solutions.

\begin{tabular}{lccc}
\hline \multirow{2}{*}{ Genotypes } & \multicolumn{3}{c}{ Seed Treatments ${ }^{\mathrm{a}}$} \\
\cline { 2 - 4 } & Control & Deltamethrin & Neem \\
\hline Yellow Broad Bean & $67.0 \pm 17.56 \mathrm{aA}$ & $25.4 \pm 7.02 \mathrm{bA}$ & $25.2 \pm 7.92 \mathrm{bA}$ \\
Cowpea & $39.2 \pm 15.82 \mathrm{aB}$ & $12.2 \pm 3.35 \mathrm{bB}$ & $13.6 \pm 5.55 \mathrm{bABC}$ \\
White Broad Bean & $17.4 \pm 10.09 \mathrm{aBC}$ & $0.6 \pm 1.34 \mathrm{bC}$ & $0.6 \pm 0.89 \mathrm{bC}$ \\
Brown Spotted Common Bean & $22.4 \pm 10.06 \mathrm{aBC}$ & $12.4 \pm 4.50 \mathrm{aB}$ & $18.2 \pm 12.70 \mathrm{aAB}$ \\
Spotted Broad Bean & $13.6 \pm 6.80 \mathrm{aC}$ & $5.4 \pm 3.13 \mathrm{bBC}$ & $6.4 \pm 2.07 \mathrm{abBC}$ \\
\hline
\end{tabular}

${ }^{\mathrm{a}}$ Means followed by at least one letter in common do not differ by Tukey's test $(\alpha=0.05)$. Capital letters stand for different genotypes in the column within each seed treatment, while the lowercase letters provide comparisons among treatments for a given genotype within a row.
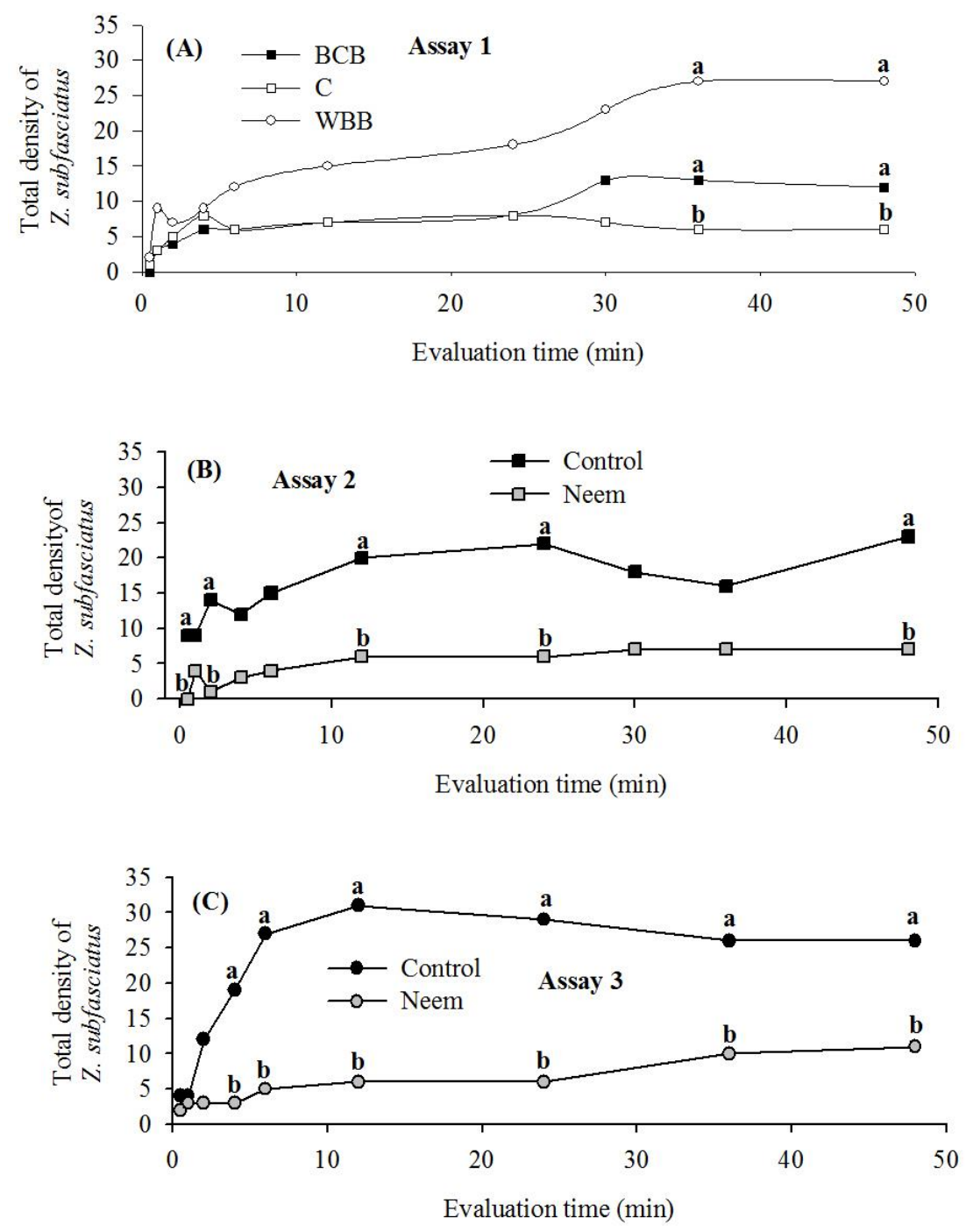

Fig 1. Total density of Zabrotes subfasciatus adults in preference (antixenosis) tests: (A) choosing a given bean genotype (20 grams samples) at different evaluation times; (B) as a function of the treatments used in the seeds; (C) as a function of the treatments used in the seeds at different evaluation times. Means followed by the same letter within a given evaluation time do not differ according to Chi-square test at $\alpha=0.05$. (Black common bean [BCB], cowpea [C] and White broad bean [WBB]). 

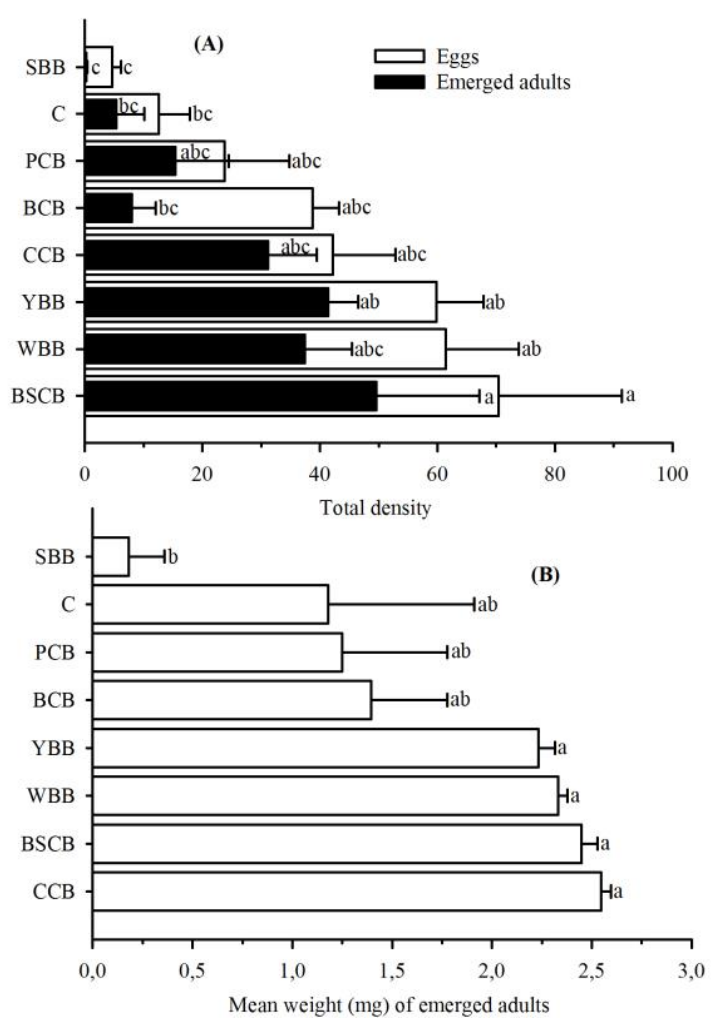

Fig 2. Total density ( \pm standard error of the mean) of eggs (white horizontal bars) and of emerged adults (black horizontal bars) (A) of Zabrotes subfasciatus in an antibiosis initial bioassay and mean weight of the emerged adults (B) according to the bean genotype tested (Black common bean [BCB]; Brown spotted common bean [BSCB]; Carnival common bean [CCB]; Cowpea [C]; Purple common bean [PCB]; Spotted broad bean [SBB]; White broad bean [WBB]; Yellow broad bean [YBB]. Means in bars of the same color followed by at least one letter in common do not significantly differ according to Tukey's test at $\alpha=0.05$.
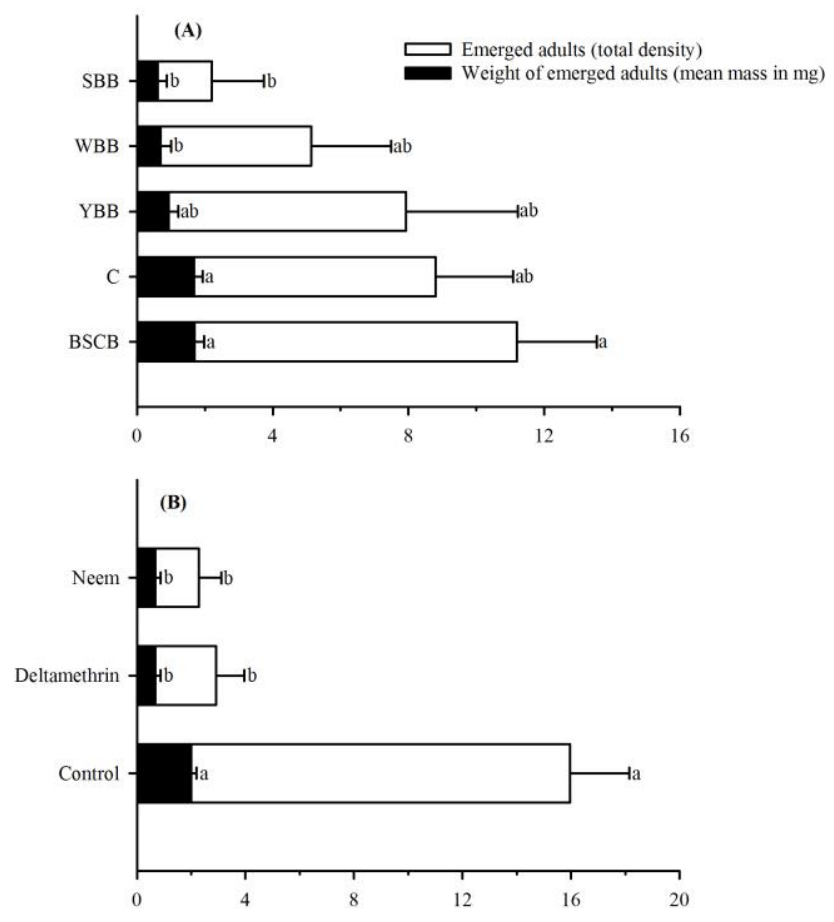

Fig 3. Total density and mean weight ( \pm standard error of the mean) of the emerged adults of Zabrotes subfasciatus obtained from an antibiosis assay as a function of: (A) the genotypes tested; (B) the treatments of the seeds. Means in bars of the same color followed by at least one letter in common do not differ by Tukey's test $(\alpha=0.05)$. *Brown spotted common bean (BSCB); Cowpea (C); Spotted broad bean (SBB); White broad bean (WBB); Yellow broad bean (YBB). 
numbers of eggs compared with control when the seeds were treated with deltamethrin (Table 1). The yellow broad bean genotype had the highest number of eggs regardless of treatment. However, when treated with neem, cowpea and brown spotted common bean had similar numbers of eggs to those observed in yellow broad bean. White broad bean had the lowest number of eggs when the seeds were insecticidetreated; spotted broad bean was the least oviposited when the seeds were water-treated (Table 1).

No significant interactions were found between insecticide treatment and genotypes for adult $Z$. subfasciatus emerged $\left(\mathrm{F}_{8,60}=1.3, P=0.2601\right)$ or the mean weight of emerged adults $\left(\mathrm{F}_{8,60}=1.8, P=0.0946\right)$. However, there were significant main effects of both beans genotypes and insecticide treatment on the densities (genotype: $\mathrm{F}_{4,60}=3.95$, $P=0.0065$; treatment: $\left.\mathrm{F}_{2,60}=32.52, P=0,0001\right)$ and mean mass (weight) (genotype: $\mathrm{F}_{4,60}=6.08, P=0.0004$; treatment: $\left.\mathrm{F}_{2,60}=20.49, P=0,0001\right)$ of emerged adults.

The density of the emerged adults was maximum in brown spotted common bean (BSCB) and minimum in spotted broad bean (SBB) genotypes (Fig 3A). However, concerning mean weight, it was maximum in both brown spotted common bean (BSCB) and cowpea (C) and minimum in both spotted broad bean (SBB) and white broad bean (WBB) (Fig 3A). Deltamethrin and neem significantly reduced the density and weight of emerged adults from treated seeds compared with the control (Fig 3B).

\section{Seed density}

Seed density varied from 1.19 to $1.50 \mathrm{~g} / \mathrm{dm}^{3}$. No significant correlations were detected between this characteristic and the number of eggs $(\mathrm{r}=-0.62, P=0.1032)$, density $(\mathrm{r}=-0.66, P$ $=0.0730)$ or mass $(\mathrm{r}=-0.68, P=0.0658)$ of emerged adults of $Z$. subfasciatus.

\section{Seed color intensity}

The values detected for the hue angle of the different genotypes varied from 16.04 to 74.81 and the values of chroma $(C)$ varied from 0.59 to 41.28 . There was no significant correlation between the number of adults of $Z$. subfasciatus choosing a given genotype and its hue angle ( $\mathrm{r}=$ $-0.19, P=0.36)$ or chroma $(\mathrm{r}=-0.24, P=0.25)$.

\section{Discussion}

The interaction between Bruchids and legume seeds is highly specific, so that only seeds of a very few species can be attacked by any of insect species (Sales et al., 2005). Despite this fact, $Z$. subfasciatus is recognized as being one of the few Bruchids able to feed on a variety of beans, including those belonging to the genera Phaseolus (common beans), Vigna (cowpea) (Sales et al., 2005; Bifano et al., 2010) and Vicia (broad beans) (Pacheco and Paula, 1995; Toledo et al., 2013). Differences in resistance of bean species to Z. subfasciatus have been well documented and are attributed to many causes, including the presence of trypsin and proteinase inhibitors, lecithins and tannins, all of which are deleterious to the development of Z. subfasciatus (Osborn et al., 1986; Posso et al., 1992; Pereira et al., 1995; Guzmán-Maldonado et al., 1996; Acosta-Gallegos et al., 1998; Barbosa et al., 2000; Aguiar et al., 2006; Moraes et al., 2011). However, many of these defenses do not seem to affect $Z$. subfasciatus, as its larvae are able to secrete $\alpha$-amylases that are insensitive to the $\alpha$-amylase inhibitor found in seeds of $P$. vulgaris (Bifano et al., 2010). This strategy has not been reported for other bruchid species feeding on $P$. vulgaris, which may explain why this host is unsuitable for them (Ishimoto and Kitamura, 1989; Hivrale et al., 2011).

Despite the relative plasticity shown by $Z$. subfasciatus during host selection, slight differences may exist in $Z$. subfasciatus preference for or performance on different beans because it is well accepted that inhibitors can be very efficient in blocking enzymes from organisms that are not specialized on that plant (Aguiar et al., 2006).

In the present study, we aimed to measure the preference of Mexican bean beetle for genotypes of different colors and found, mostly that preference did not differ significantly among the tested genotypes. Only in one assay we observed alteration in preference of two out of ten measures taken (Fig 1A), with the white broad bean and the brown common bean being the most and cowpea the least preferred genotypes. However, cowpea and spotted broad bean altered some biological characteristics of $Z$. subfasciatus, greatly reducing the oviposition and density of emerged adults (Fig 2A). Additionally, spotted broad bean greatly reduced the weight of emerged adults of Z. subfasciatus (Fig 2B), making it the most antibiotic genotype tested. Previous work has also demonstrated that different cultivars of cowpea can alter the damage caused by another bruchidae (Callosobruchus maculatus [Fabricius]), reducing insect emergence and population growth, and increasing mortality (Torres et al., 2016). Hence, the cowpea genotype used in this work must have been unsuitable to $Z$. subfasciatus development the same way that the cultivars BRS Tapaihum and BRS Acauã were to $C$. maculatus.

We observed no relationship between the density of seeds and biological characteristics of the beetle. Hence, some other causes, not measured here, might be involved including the chemical composition of seeds (Barbosa et al., 2000; Minney et al., 1990). This and other possibilities should be investigated in future work.

Despite this finding, some of the patterns that we detected suggest potential synergism of control tactics included in an IPM approach. The use of multiple strategies and tactics is the basic principle of IPM (Gray et al., 2009). This integration, if synergistic, may result in efficacy of combined tactics that would fail in isolation. Thus, one can search for moderate resistance levels and pesticides causing lower rates of mortality without discarding either tactic for further use in pest control. Such an approach is especially useful for cosmopolitan pests and systems with few management options, such as the case for Z. subfasciatus infesting bean seeds.

When we treated genotypes possessing variable degrees of antibiosis resistance with one botanical and one synthetic insecticide, we noticed a large reduction in pest density including a $20-50 \%$ reduction in oviposition, even among highly susceptible genotypes, such as the brown spotted common bean (Table 1). For moderately and highly resistant genotypes, such as white and spotted broad bean, the reduction in oviposition varied from $53 \%$ to nearly $100 \%$ (Table 1) and was reflected in the number of adults emerging from these genotypes, which were half and five times less numerous than those emerging from the susceptible genotype (brown spotted common bean) (Fig 3A). Additionally, the adults emerging from those genotypes had only approximately $35 \%$ to $40 \%$ of the mass of those emerging from the susceptible genotype (Fig 3A).

Our results, therefore, suggest a synergistic effect of using genotypes possessing moderate and high level of resistance and chemical control with alternative pesticides (to the fumigants that are currently used). The synergistic effect observed here is similar to that described by Mazzoneto and Vendramin (2002). According to these results, the adoption 
of alternative measures of control in isolation should be avoided because they are not expected to yield effective control of the pest.

The comparison between a neem formulation and control in preference tests showed that it may greatly reduce the infestation from $53.33 \%$ to $100 \%$ (Fig 1B) and from $40.54 \%$ to $72.72 \%$ (Fig 1C) depending on the evaluation time. Also, in the antibiosis assay the neem-based formulation was as efficient as deltamethrin in reducing infestation (Table 1).

The results showing comparable efficiency of neem's formulation to a synthetic insecticide (deltamethrin) used to control Z. subfasciatus agree with results from Barbosa et al. (2002), who compared a neem oil formulation with malathion. Hence, neem-based formulations should be preferred over synthetic pesticides because neem-based formulations degrade rapidly (Johnson et al., 2003) and thus may reduce the amount of residues on the final product, which will be consumed by humans.

\section{Materials and Methods}

\section{Plant materials}

The tested genotypes comprised the following groups: a) Phaseolus vulgaris group: carnival common bean (CCB), brown spotted common bean (BSCB), black common bean (BCB) and purple common bean (PCB); b) Vicia faba group: yellow broad bean (YBB), white broad bean (WBB) and spotted broad bean (SBB); and c) the Vigna unguiculata group: cowpea (C) and greenly cowpea (GC). These samples were obtained from open markets, cataloged and morphologically described for the following characteristics: 1) husk and hilo colors; 2) width $x$ length ratio; 3) diameter; 4) 100-seed mass; and 5) shape of the seed [data not shown in this manuscript], according to the methodology described in Silva (2005). Seeds were stored in a freezer to prevent infestation.

\section{Insects}

Insects used in the assays were manually transferred from mass rearing colonies maintained on $P$. vulgaris seeds (group Carioquinha), a variety not included among the tested genotypes. The mass rearing procedures followed those described by Baldin and Pereira (2010) which used transparent glass vial of $1 \mathrm{~L}$ volume covered with a lid containing a screen (35 mesh) and that was filled with $300 \mathrm{~g}$ of grains and received around 300 insects. Colonies started with insects obtained from infested beans sold at open markets which were totally infested and damaged.

\section{Experimental design and conditions}

The treatments of the antibiosis and antixenosis bioassays were arranged in a randomized design with five replications. Antibiosis bioassays were run under controlled environment within a B.O.D. set to $25 \pm 2{ }^{\circ} \mathrm{C}$ and a 12:12 h L:D photophase. Further, non-preference bioassays were run under normal lab conditions. We kept record of that data using an Instrutemp ITLog 80 data logger, with measurements taken every 30 minutes.

\section{Non-preference (antixenosis) bioassays}

In the initial assay (without insecticide treatment), six genotypes [white broad bean (WBB), spotted broad bean (SBB), cowpea (C), greenly cowpea (GC), black common bean (BCB) and purple common bean (PCB)] were tested. A foam arena containing 30 holes, designed to precisely fit plastic container (50 mL volume), was built. The edges of the cups were leveled with the surface of the foam platform.

To each plastic container, we added $20 \mathrm{~g}$ of seeds of one of the bean species (i.e., five replicate cups per each of the six genotypes). Then, $60 \mathrm{Z}$. subfasciatus adults were released in the center of the arena. The number of insects on each genotype was evaluated after $0.5,1.0,2.0,4.0,6.0,12.0$, $22.0,30.0$ and $48 \mathrm{~h}$ from the beginning of the assay. These data were used to select the most and least preferred genotypes to be further tested in combination with a neem formulation in three other bioassays. Then, in the final assays (with insecticide treatment) for each tested genotype, $20 \mathrm{~g}$ of seed samples were treated with an oil-based formulation of neem (Natuneem ${ }^{\circledR}$, Manufacturer: Natural Rural Ind. e Com. de Produtos Biológicos Ltda., Araraquara, SP, Brazil) at the rate of $3 \mathrm{~mL}$ of commercial product (formulation) per $30 \mathrm{~mL}$ of distilled water or distilled water (control) using manual polyethylene sprayers with a capacity of $250 \mathrm{~mL}$. The seeds were maintained at room temperature and humidity $\left(25 \pm 3^{\circ} \mathrm{C}\right.$ and $50 \pm 20 \%$ r.h.) until they were dry and were then added into the arena. The experimental conditions, the number of insects released and variables measured followed the same procedure as that described for the initial assay. The evaluations were performed at $0.5,1.0,2.0,4.0,6.0,12.0$, 22.0, 30.0 and $48 \mathrm{~h}$ after the beginning of the third bioassay run with neem-treated seeds. The other two bioassays included an additional evaluation time, at $36 \mathrm{~h}$ after the beginning of the assay.

\section{Antibiosis bioassays}

In the initial assay (without insecticide treatment), eight genotypes [black common bean (BCB), brown spotted common bean (BSCB), carnival common bean (CCB), cowpea (C), purple common bean (PCB), white broad bean (WBB), spotted broad bean (SBB) and yellow broad bean (YBB)] were tested. A single glass vial (20 mL volume), containing $20 \mathrm{~g}$ of seeds, was infested with five female adults of Z. subfasciatus. We chose only females to be used in experimental units since they are easily recognized for their body size and color pattern (Kaur et al., 1999). The vials were lidded and kept within a B.O.D set up to the aforementioned conditions for seven days. After this time, the adults were removed and the eggs counted. Then, the vials were returned to the B.O.D and the emergence of adults was recorded daily. After the emergence of the first adult, evaluations were maintained for the following 20 days. Emerged adults were recorded daily and weighed in an analytical electronic balance (model FA-2104N). The total mass was divided by the total number of adults obtained and used to estimate the mean mass, which was used in the statistical analysis.

The results obtained in the initial bioassay were used to select five genotypes having variable degrees of resistance or susceptibility, which were tested in a subsequent assay (final assay - with insecticide treatment). Each of the selected genotypes were exposed to one of three treatments: distilled water (as a control), deltamethrin (Decis $25 \mathrm{CE}$, Manufacturer: Bayer S/A, São Paulo, SP, Brazil) at the rate of $0.1 \mathrm{~mL}$ of commercial product (formulation) per $30 \mathrm{~mL}$ of distilled water and an oil based neem formulation (Natuneem ${ }^{\circledR}$ ) at the rate of $3 \mathrm{~mL}$ of commercial product (formulation) per $30 \mathrm{~mL}$ of distilled water. The condition and number of insects confined and seeds used, as well as the variables measured, followed the same procedure described for the initial assay. 


\section{Seed density}

Samples of $50 \mathrm{~g}$ of each of the genotypes included in the initial antibiosis assay were added to dry graduated cylinders, which then received $150 \mathrm{~mL}$ of distilled water. The volume of samples + water were recorded and these measures were used to calculate real density (RD) according to the following formula: $\mathrm{RD}=$ (mass of seeds) $/[$ (volume of distilled water + seeds) - (volume of distilled water)]. All determinations were carried out with five replicates for each genotype.

\section{Seed color intensity}

Color intensity of the seeds included in the initial antixenosis assay was determined using a Minolta Colorimeter CR-200 (Minolta Camera Co., Osaka, Japan). Data were presented as $L-, a$ - and $b$-values of the Hunter color system, where $L$ represents lightness (values range from 0 to 100 , dark to light) and the $a$ - and $b$-values are chromatic components of $(+)$ redness to $(-)$ greenness and $(+)$ yellowness to $(-)$ blueness, respectively. All determinations were carried out with five replicates for each genotype. The $a$ - and $b$-values were used to calculate Hue angle $(h)$ and chroma $(C)$ according to the following equations (Maskan, 2001):

$$
\begin{gathered}
h=\tan -1(\mathrm{~b} / \mathrm{a}) \\
\mathrm{C}=(\mathrm{a} 2+\mathrm{b} 2) 1 / 2
\end{gathered}
$$

\section{Data analysis}

Because data from the three different initial antixenosis assays showed no significant differences among the same treatments of different assays [by PROC GLM of the SAS System (SAS, 2002)], they were reduced to overall means. Initial antixenosis assay was transformed to square root $(\mathrm{x}+0.5)$ to fit the analysis of variance assumptions and submitted to repeated measures ANOVA [by PROC GLM of the SAS System (SAS, 2002)]. This was followed by comparisons of means by Tukey's test at $\alpha=0.05$. The data coming from the subsequent antixenosis assays (final assays with neem-formulation treatment) were submitted to Chisquare test to evaluate differences between the numbers of insects present in neem treated seeds in different evaluation times. Also, it was used to detect differences among the genotypes in different evaluation times. In this analysis, the expected values of Chi-square were taken assuming an equal distribution of $Z$. subfasciatus among treatments and the observed values were derived from the number of insects found on each treatment within a given evaluation time.

The remaining data were subjected to one-way (antibiosis initial assay) or two-way (insecticide-treated antibiosis assay) ANOVA followed by comparison of means by Tukey's test at $\alpha=0.05$. The data were also tested for a relationship of mean density and color intensity of seeds using Pearson correlation analysis at $\alpha=0.05$. Color intensity was correlated with overall mean density of insects throughout the evaluations' time in the initial preference (antixenosis) assay, since in this test the insect had the chance to choose among materials possessing different colors while the same did not happen in no-chance tests. Density of the seeds was correlated with total number of eggs and emerging adults and with the mean weight of the emerged adults in the initial antibiosis assays, in a way to try to account for the possible antibiosis effects observed.
Z. subfasciatus adults exhibited similar preference among non-treated bean genotypes, although neem-treated genotypes altered the preference and reduced infestation from 40.54$100 \%$. The less preferred genotype was cowpea (C). The most antibiotic genotype was spotted broad bean (SBB) once oviposition, density and the weight of emerged adults of $Z$. subfasciatus was reduced while in this genotype. Insecticides (both deltamethrin and neem) reduced oviposition about 53$100 \%$ and yielded half to five-fold fewer emerging insects weighting $35 \%-40 \%$ less in antibiotic genotypes. Both insecticides synergized with the genotypes possessing high degrees of antibiosis, reducing oviposition in 53-96\%.

\section{Acknowledgments}

The authors thank Conselho Nacional de Desenvolvimento Científico e Tecnológico $(\mathrm{CNPq})$ for financial support and scholarships given to the authors. The authors are also grateful for financial support received concerning publication fees by Fundação de Empreendimentos Científicos e Tecnológicos (Finatec) and Decanato de Pós-graduação of the University of Brasilia (UnB).

\section{References}

Acosta-Gallegos JA, Quintero C, Vargas J, Toro O, Tohme J, Cardona C (1998) A new variant of arcelin in wild common bean, Phaseolus vulgaris L., from southern Mexico. Genet Resour Crop Ev. 45: 235-242.

Aguiar JM, Franco O, Rigden DJ, Bloch Jr C, Monteiro ACS, Flores VMQ, Jacinto T, Xavier-Filho J, Oliveira AEA, Grossi-de-Sá MF, Fernandes KVS (2006) Molecular modeling and inhibitory activity of cowpea cystatin against bean bruchid pests. Proteins: Struct Funct Bioinf. 63: 662670

Baldin ELL, Pereira JM (2010) Resistência de genótipos de feijoeiro a Zabrotes subfasciatus (Bohemann, 1833) (Coleoptera: Bruchidae). Cienc Agrotec. 34: 1507-1513.

Barbosa FR, Yokoyama M, Pereira PAA, Zimmermann FJP (2000) Danos de Zabrotes subfasciatus (Boh.) (Coleoptera: Bruchidae) em linhagens de feijoeiro (Phaseolus vulgaris L.) contendo arcelina. An Soc Entomol Bras. 29: 113-121.

Barbosa FR, Yokoyama M, Pereira PAA, Zimmermann FJP (2002) Controle do caruncho-do-feijoeiro Zabrotes subfasciatus com óleos vegetais, munha, materiais inertes e malathion. Pesqui Agropecu Bras. 37: 1213-1217.

Bifano TD, Samuels RI, Alexandre D, Silva CP (2010) Host mediated induction of $\alpha$-amilases by larvae of the mexican bean weevil Zabrotes subfasciatus (Coleoptera: Chrysomelidae: Bruchinae) is irreversible and observed from initiation of the feeding period. Arch Insect Biochem. 74: 247-260.

Brackmann A, Neuwald DA, Ribeiro ND, Freitas ST (2002) Conservation of three bean genotypes (Phaseolus vulgaris L.) of the group carioca in cold storage and controlled atmosphere. Cienc Rural. 32: 911-915.

Brasil. Ministério da Agricultura, Pecuária e Abastecimento (MAPA). (2017) Agrofit: sistema de agrotóxicos fitossanitários. Brasília, DF, Brazil (online source).

Frota KMG, Soares RAM, Arêas JAG (2008) Composição química do feijão caupi (Vigna unguiculata L. Walp), cultivar BRS-Milênio. Ciencia Tecnol Alime. 28: 470-476.

Gray ME, Ratcliffe ST, Rice ME (2009) The IPM paradigm: concepts, strategies and tactics. In: Radcliffe EB, Hutchinson WD, Cancelado RE (eds) Integrated pest management: concepts, tactics, strategies and case studies. Cambridge University Press, Cambridge, UK. 1.

\section{Conclusion}


Gutierrez BA, Schoonhoven AVan (1981) Proteja su cosecha de fríjol contra el ataque de lós gorgojos, Boletín Divulgativo 66, Instituto Colombiano Agropecuario, Palmira, Colombia.

Guzmán-Maldonado SH, Marín-Jarillo A, Castellanos JZ, González de Mejía E, Acosta-Gallesgosc JA (1996) Relationship between physical and chemical characteristics and susceptibility to Zabrotes subfasciatus (Boh.) (Coleoptera: Bruchidae) and Acanthoscelides obtectus (Say) in common bean (Phaseolus vulgaris L.) varieties. J Stored Prod Res. 32: 53-58.

Hill DS (2002) Pests of stored foodstuffs and their control. Kluwer Academic Publishers, Secaucus, New Jersey, USA.

Hivrale VK, Chougule NP, Giri AP, Chhabda PJ, Kachole MS (2011) Biochemical characterization of $\alpha$-amylase inhibitors from Achyranthes aspera and their interactions with digestive amylases of coleopteran and lepidopteran insects. J Sci Food Agric. 91: 1773-1780.

Ishimoto M, Kitamura K (1989) Growth inhibitory effects of an a-amylase inhibitor from kidney bean, Phaseolus vulgaris (L.) on three species of bruchids (Coleoptera: Bruchidae). Appl Entomol Zool. 24: 281-286.

Johnson S, Dureja P, Dhingra S (2003) Photostabilizers for azadirachtin-A (a neem-based pesticide). J Environ Sci Heal B. 38: 451-462.

Kaur D, Pajni HR, Tewari PK (1999) Morphological and reproductive dimorphism in Zabrotes subfasciatus (Boh.). In: Jin Z, Liang Q, Liang Y, Tan X, Guan, L (eds) Proceedings of the seventh international working conference on stored-product protection, October 14-19, 1998, Sichuan Publishing House of Science and Technology, Beijing, Chengdu, China

Magalhães CP, Fragoso RR, Souza DSL, Barbosa AEAD, Silva CS, Finardi-Filho F, Silva MCM, Rocha TL, Franco OL, Grossi-de-Sa MF (2007) Molecular and structural characterization of a trypsin highly expressed in larval stage of Zabrotes subfasciatus. Arch Insect Biochem. 66: 169-182.

Maskan M (2001) Kinetics of colour change of kiwifruits during hot air and microwave drying. J Food Eng. 48: 169175.

Mazzoneto F, Vendramim JD (2002) Aspectos biológicos de Zabrotes subfasciatus (Boh.) (Coleoptera: Bruchidae) em genótipos de feijoeiro com e sem arcelina. Neotrop Entomol. 31: 435-439.

Minney BHP, Angharad MR, Dobie P, Dendy J, Cardona C, Gatehouse JA (1990) Biochemichal bases of seed resistante to Zabrotes subfasciatus (bean weevil) in Phaseolus vulgaris (common beans); a mechanism for arcelin toxicity. J Insect Physiol. 10: 757-767.

Moraes CPB, Boiça-Júnior AL, Souza JR, Costa JT (2011) Determinação dos tipos de resistência em genótipos de feijoeiro ao ataque de Zabrotes subfasciatus (Coleoptera: Bruchidae). Rev Ceres 58: 419-424.
Osborn TC, Blake T, Gepts G, Bliss FA (1986) Bean arcelin 2. Genetic variation, inheritance and linkage relationships of a novel seed protein of Phaseolus vulgaris L. Theor Appl Genet. 71: 847-855.

Pacheco IA, Paula DC (1995) Insetos de grãos armazenados: identificação e biologia. Fundação Cargill, Campinas, São Paulo, Brazil.

Pereira PAA, Yokoyama M, Quintela ED, Bliss FA (1995) Controle do caruncho Zabrotes subfasciatus (Boheman, 1833) (Coleoptera-Bruchidae) pelo uso de proteína da semente em linhagens quase-isogênicas de feijoeiro. Pesqui Agropecu Bras. 30: 1031-1034.

Posso CE, Cardona C, Valor JF, Morales H (1992) Desarrollo de lineas de frijol resistentes al gorgojo Zabrotes subfasciatus (Boheman) (Coleoptera: Bruchidae). Rev Colomb Entomol. 18: 8-13.

Sales MP, Andrade LBS, Ary MB, Miranda MRA, Teixeira FM, Oliveira AS, Fernandes KVS, Xavier-Filho J (2005) Performance of bean bruchids Callosobruchus maculatus and Zabrotes subfasciatus (Coleoptera: Bruchidae) reared on resistant (IT81D-1045) and susceptible (Epace 10) Vigna unguiculata seeds: relationship with trypsin inhibitor and vicilin excretion. Comp Biochem Phys A. 142: 422426.

SAS Institute (2002) The sas system for Windows, Release 9.00. Sas Inst., Cary, NC, USA.

Silva HT (2005) Descritores mínimos indicados para caracterizar cultivares/variedades de feijão comum (Phaseolus vulgaris L.), Documentos 184, Embrapa Arroz e Feijão, Goiânia, Goiás, Brazil.

Smith CM (2005) Introduction. In: Smith CM (ed) Plant resistance to arthropods. Springer, Dordrecht, Netherlands. 1.

Toledo AVK, Fontes LS, Barbosa DRS, Silva PRR, Neves JA, Melo RS (2013) Resistance of cowpea genotypes to Zabrotes subfasciatus (Boheman,1833) (Coleoptera: Chrysomelidae: Bruchinae). J Agr Sci. 5: 83-90.

Torres EB, Nóbrega RSA, Fernandes-Júnior PI, Silva LB, Carvalho GS, Marinho, RCN, Pavan BE (2016) The damage caused by Callosobruchus maculatus on cowpea grains is dependent on the plant genotype. J Sci Food Agr. 96: 4276-4280. 